\begin{tabular}{|c|c|c|c|c|c|c|}
\hline \multirow{4}{*}{ Impact Factor: } & ISRA (India) & $=3.117$ & SIS (USA) & $=0.912$ & ICV (Poland) & $=6.630$ \\
\hline & ISI (Dubai, UAE & $=0.829$ & РИНЦ (Russia & $=0.156$ & PIF (India) & $=1.940$ \\
\hline & GIF (Australia) & $=0.564$ & ESJI (KZ) & $=8.716$ & IBI (India) & $=4.260$ \\
\hline & JIF & $=1.500$ & SJIF (Morocco & $=5.667$ & OAJI (USA) & $=0.350$ \\
\hline
\end{tabular}

\section{SOI: $1.1 /$ TAS $\quad$ DOI: $10.15863 /$ TAS \\ International Scientific Journal Theoretical \& Applied Science}

p-ISSN: 2308-4944 (print) e-ISSN: 2409-0085 (online)

Year: 2019 Issue: $07 \quad$ Volume: 75

Published: 04.07.2019 http://T-Science.org
QR - Issue

QR - Article
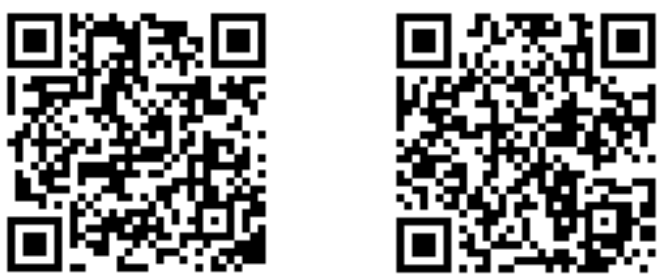

Denis Chemezov

Vladimir Industrial College

M.Sc.Eng., Corresponding Member of International Academy of Theoretical and Applied Sciences, Lecturer, Russian Federation https://orcid.org/0000-0002-2747-552X

chemezov-da@yandex.ru

Irina Pavluhina

Vladimir Industrial College Lecturer, Russian Federation

Andrey Komissarov

Vladimir Industrial College Master of Industrial Training, Russian Federation

Ivan Kanishchev

Vladimir Industrial College

Student, Russian Federation

\title{
PROPERTIES RESEARCH OF GREY CAST IRON IN CONDITION OF GRAVITY CASTING INTO A METAL MOLD
}

Abstract: A transition process of liquid phase of grey cast iron into solid phase when gravity casting into a metal mold was considered in the article. Properties changes of grey cast iron when filling of the metal mold with melt and its subsequent cooling are presented graphically. An analysis of residual stresses in a casting material after crystallization is given.

Key words: casting, a metal mold, melt, filling, crystallization, grey cast iron.

Language: English

Citation: Chemezov, D., Pavluhina, I., Komissarov, A., \& Kanishchev, I. (2019). Properties research of grey cast iron in condition of gravity casting into a metal mold. ISJ Theoretical \& Applied Science, 07 (75), 1-4.

Soi: http://s-o-i.org/1.1/TAS-07-75-1 Doi: crossef https://dx.doi.org/10.15863/TAS.2019.07.75.1

Classifiers: Metallurgy and energy.

\section{Introduction}

Casting is the most common method of manufacturing of cast iron billets of various geometric shapes. The each method of casting includes a number of the complex simultaneously occurring physical processes: hydrodynamic, thermal, crystallization [1 10] and etc. Castings made of grey cast iron of normal accuracy can be obtained by gravity casting. A metal mold provides multiple casting of complex in the shape of the castings. The process of gravity casting consists of two main stages: filling of the mold with melt and gradual cooling of melt before complete crystallization. Transition of liquid phase of metal alloy into solid phase (which is accompanied by various phase transformations) is observed as a result of occurring of these processes. More accurate deformation models of the billet and melt crystallization of grey cast iron can be obtained when taking of readings from sensors mounted on the threedimensional model of the manufactured casting. The three-dimensional model of a car piston, which has thin-walled and massive elements, was used as the researched casting.

\section{Materials and methods}

The properties research of grey cast iron when cooling in the mold was carried out by finite element modeling. The process of gravity casting of grey cast 


\begin{tabular}{|c|c|c|c|c|c|c|}
\hline \multirow{4}{*}{ Impact Factor: } & ISRA (India) & $=3.117$ & SIS (USA) & $=0.912$ & ICV (Poland) & $=6.630$ \\
\hline & ISI (Dubai, UAE & $=0.829$ & РИНЦ (Russia & $=0.156$ & PIF (India) & $=1.940$ \\
\hline & GIF (Australia) & $=0.564$ & ESJI (KZ) & $=8.716$ & IBI (India) & $=4.260$ \\
\hline & JIF & $=1.500$ & SJIF (Morocce & $=5.667$ & OAJI (USA) & $=0.350$ \\
\hline
\end{tabular}

iron (EN-GJL-300) into the metal mold made of grey cast iron was simulated. Melt of grey cast iron was exposed by casting at the initial temperature of $1290^{\circ} \mathrm{C}$. Melt was poured into the metal mold at the speed of $0.4 \mathrm{~kg} / \mathrm{s}$. The mass of the casting model was $1.279 \mathrm{~kg}$. The metal mold was heated to $200^{\circ} \mathrm{C}$ for maintenance of heat. Melt cooling in the metal mold was performed before complete crystallization (liquid phase is zero). The computer simulation of the gravity casting process was close to the real process by specifying of gas data when filling of the metal mold with melt and convection.

\section{Results and discussion}

The calculation results are presented in a form of the dependencies of the properties changes of grey cast iron when filling of the metal mold with melt (the Fig. 1) and cooling (the Fig. 2).

These volumes of the metal mold cavities are filled with melt of grey cast iron for $3.6 \mathrm{~s}$. The crystallization process of the casting was $26.611 \mathrm{~s}$. The casting cooling is accompanied by decreasing of the material volume by $1.52 \%$.
$\boldsymbol{A}$

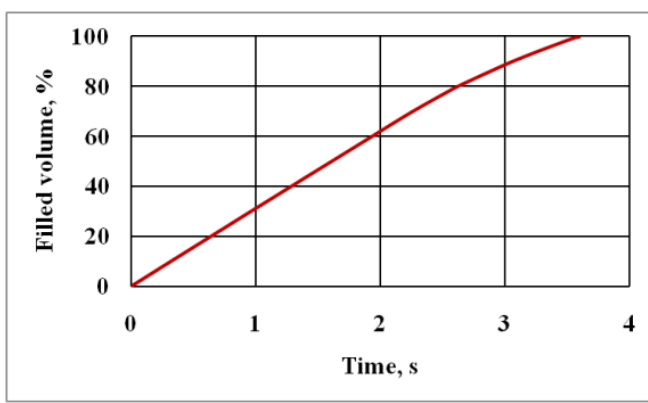

C

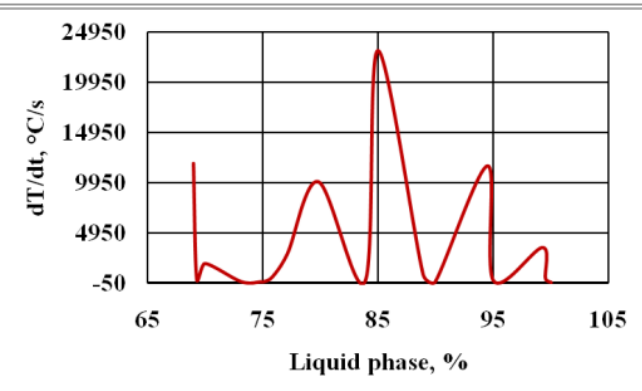

$\boldsymbol{E}$

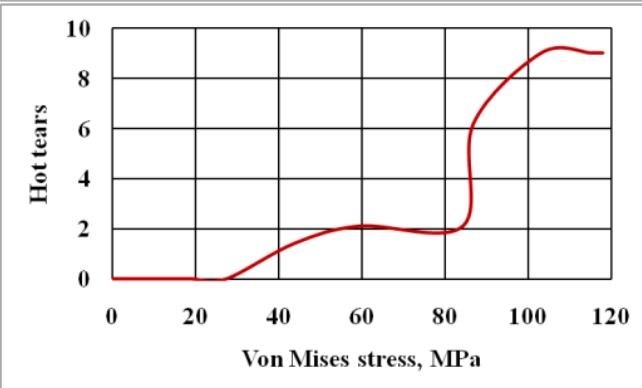

G

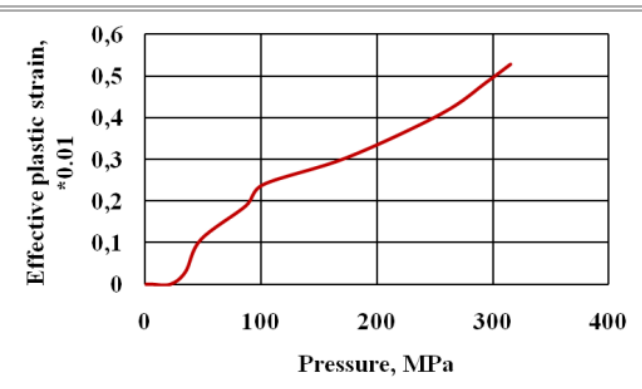

$\boldsymbol{B}$

D
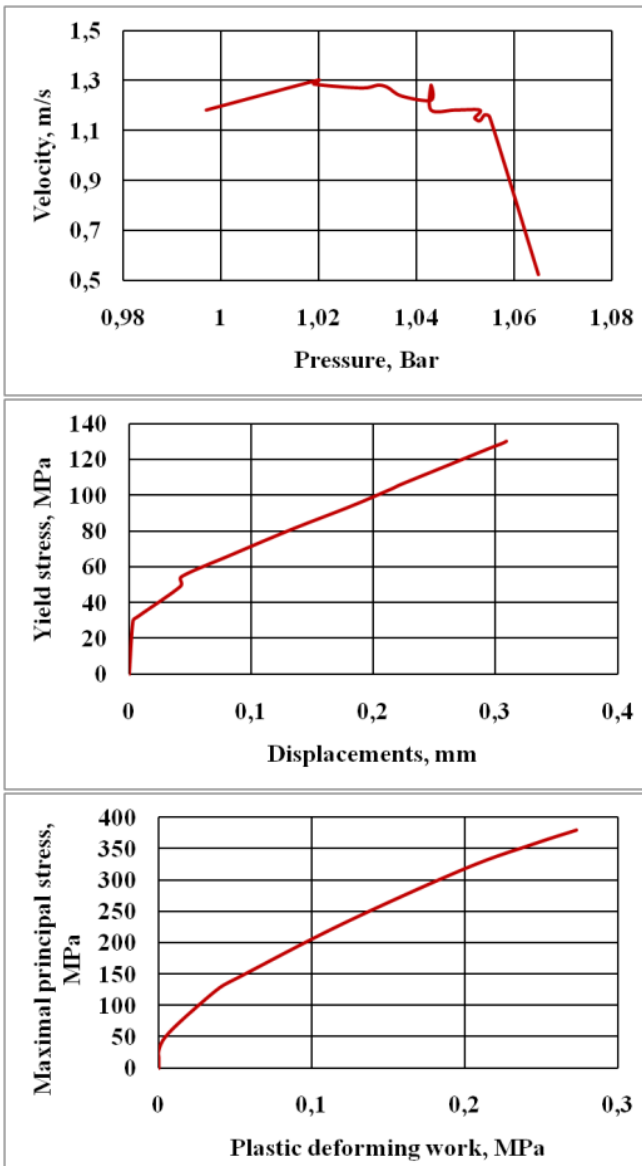

Plastic deforming work, MPa

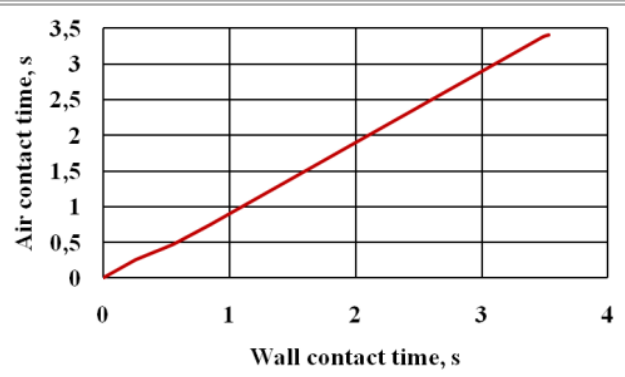

Figure 1 - The properties changing of grey cast iron melt when filling of the metal mold: $A$ - the filled volume of the metal mold with grey cast iron from time of filling; $B$ - velocity of grey cast iron from pressure; $C$ - cooling rate of grey cast iron from the percentage of liquid phase; $D$-yield stress of grey cast iron from displacements; $\boldsymbol{E}$ - hot tears in grey cast iron from von Mises stress; $\boldsymbol{F}$ - maximal principal stress in grey cast iron from plastic deforming work; $G$ - effective plastic strain in grey cast iron from pressure; $H$ - air contact time from wall contact time. 


\begin{tabular}{llllll} 
& ISRA (India) $=\mathbf{3 . 1 1 7}$ & SIS (USA) & $=\mathbf{0 . 9 1 2}$ & ICV (Poland) & $\mathbf{= 6 . 6 3 0}$ \\
Impact Factor: & ISI (Dubai, UAE) $=\mathbf{0 . 8 2 9}$ & PUHL (Russia) $=\mathbf{0 . 1 5 6}$ & PIF (India) & $=\mathbf{1 . 9 4 0}$ \\
& GIF (Australia) $=\mathbf{0 . 5 6 4}$ & ESJI (KZ) & $=\mathbf{8 . 7 1 6}$ & IBI (India) & $=\mathbf{4 . 2 6 0}$ \\
& JIF & $\mathbf{1 . 5 0 0}$ & SJIF (Morocco) $=\mathbf{5 . 6 6 7}$ & OAJI (USA) & $\mathbf{0 . 3 5 0}$ \\
\hline
\end{tabular}

$\boldsymbol{A}$

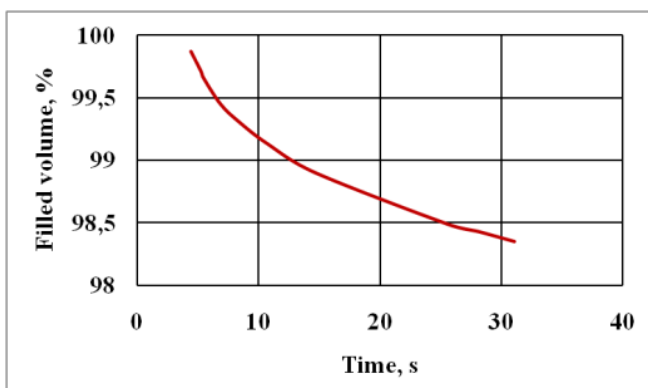

$C$
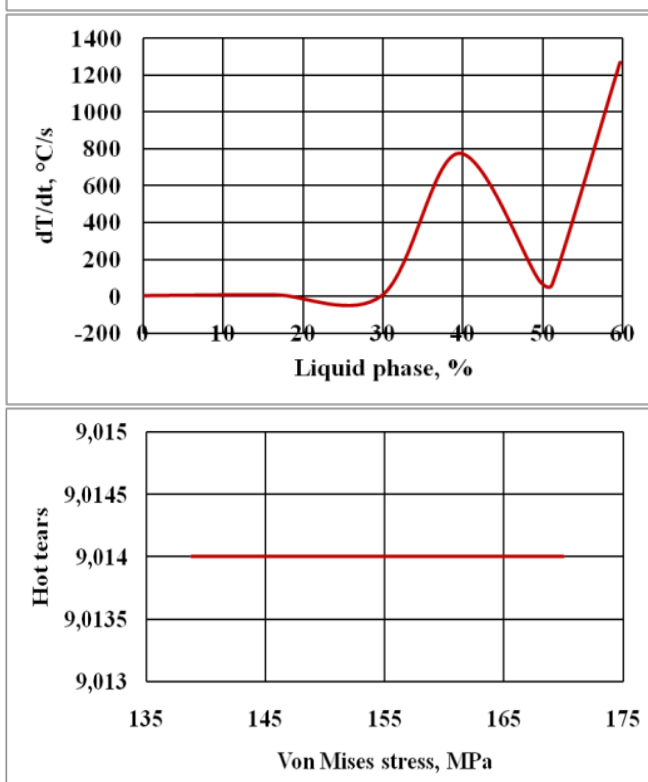

$\boldsymbol{G}$

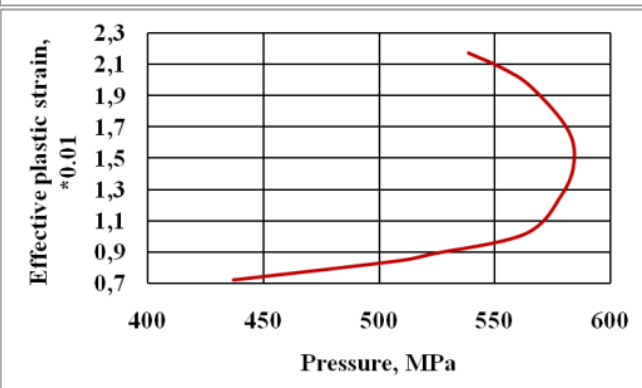

$\boldsymbol{B}$

$D$
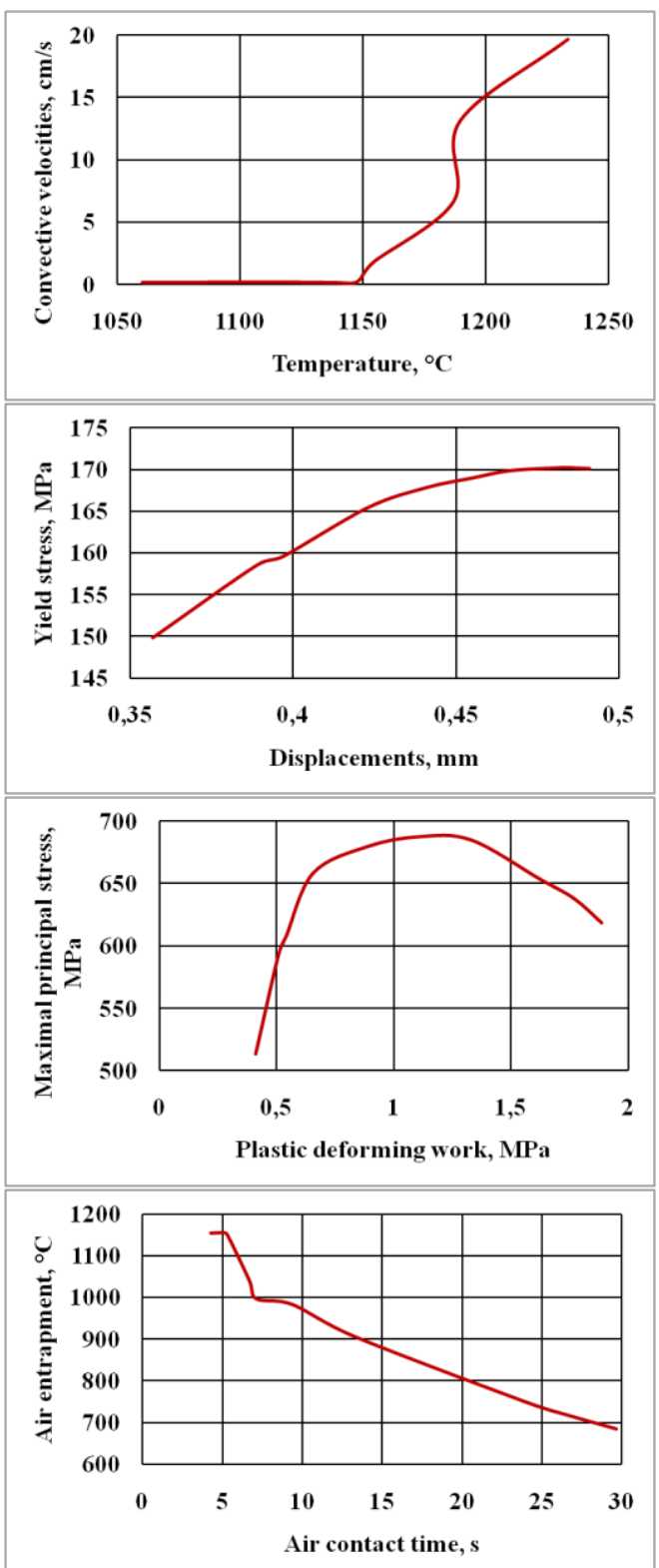

Figure 2 - The properties changing of grey cast iron melt when crystallization: $A$ - the filled volume of the metal mold with grey cast iron from time of crystallization; $B$ - convective velocities in grey cast iron from temperature; $C$-cooling rate of grey cast iron from the percentage of liquid phase; $D$-yield stress of grey cast iron from displacements; $\boldsymbol{E}$ - hot tears in grey cast iron from von Mises stress; $\boldsymbol{F}$ - maximal principal

stress in grey cast iron from plastic deforming work; $G$ - effective plastic strain in grey cast iron from pressure; $\boldsymbol{H}$ - air entrapment from air contact time.

Melt velocity decreases and pressure increases by $6.5 \%$ when filling of the cavities volumes of the metal mold. Convective flows in melt are observed only when cooling. Crystallization of grey cast iron occurred when cooling of melt to $200^{\circ} \mathrm{C}$ from the initial temperature. Melt of grey cast iron is cooled from beginning of the filling process of the metal mold. Significant jumps of cooling rate of melt are observed at $85 \%$ of liquid phase. Cooling rate of grey cast iron becomes constant in the range of liquid phase from 20 to $0 \%$. Yield stress of grey cast iron has maximum growth at the filling stage of the metal mold with melt. Yield stress of the casting changes by only $15 \%$ when crystallization. Residual von Mises stresses of $170 \mathrm{MPa}$ occur in grey cast iron after casting. Growth of stresses when crystallization of grey cast iron changes by only $20 \%$. Growth intensity of hot tears is observed only in liquid phase of grey cast iron from 100 to $70 \%$. Maximal principal stress of grey cast iron increases at the filling stage and partly at the crystallization stage. Decreasing of the casting stress is observed at a liquid phase boundary 


\begin{tabular}{|c|c|c|c|c|c|c|}
\hline \multirow{4}{*}{ Impact Factor: } & ISRA (India) & $=3.117$ & SIS (USA) & $=0.912$ & ICV (Poland) & $=6.630$ \\
\hline & ISI (Dubai, UAE & $=0.829$ & РИНЦ (Russia & $=0.156$ & PIF (India) & $=1.940$ \\
\hline & GIF (Australia) & $=0.564$ & ESJI (KZ) & $=8.716$ & IBI (India) & $=4.260$ \\
\hline & JIF & $=1.500$ & SJIF (Morocce & $=5.667$ & OAJI (USA) & $=0.350$ \\
\hline
\end{tabular}

of grey cast iron equal to $20 \%$. Maximum intensity of plastic deforming work of grey cast iron was determined when crystallization. Residual pressure of grey cast iron in the end of the crystallization process is decreased. Effective plastic strain in material of the cooled casting is 3 times higher than in melt. Contact of grey cast iron melt with the metal mold wall lasts for $0.12 \mathrm{~s}$ more than contact of melt with air at the filling stage. During crystallization of grey cast iron, the air temperature in the metal mold decreases to $685.706 \mathrm{~K}$, which is almost 2 times less than the temperature of the casting material.

\section{Conclusion}

The filling process of the metal mold with melt of grey cast iron is accompanied by a significant release of thermal energy and changing of the other properties. Maximum growth of stresses of various kinds occurs in a short period of time in grey cast iron. Decreasing of maximal principal stress and pressure of grey cast iron by $10 \%$ of the highest value at a ratio of solid and liquid phases of 83 and $17 \%$ was observed.

\section{References:}

1. Chemezov, D., Smirnova, L., \& Bogomolova, E. (2018). Metal mold casting of cast iron and aluminium pistons. ISJ Theoretical \& Applied Science, 05 (61), 132-141.

2. Chemezov, D., Osipov, T., Pesenko, A., Komarova, T., Aronova, I., \& Lukyanova, T. (2018). Hardness determination of a cast iron piston after metal mold casting. ISJ Theoretical \& Applied Science, 05 (61), 201-203.

3. Chemezov, D. (2018). Condition of a casting material of a cylinder block of a car after crystallization in a sand mold. ISJ Theoretical \& Applied Science, 07 (63), 145-147.

4. Chemezov, D. (2017). Convective heat transfer when cooling of metallic melts. ISJ Theoretical \& Applied Science, 09 (53), 1-7.

5. Chemezov, D. (2017). The mathematical models of shrinkage formation in metallic alloys. ISJ Theoretical \& Applied Science, 09 (53), 23-42.
6. Chemezov, D. (2017). The degree of shrinkage porosity in the castings after solidification. ISJ Theoretical \& Applied Science, 07 (51), 1-6.

7. Chemezov, D., Bakhmeteva, M., Bayakina, A., Polushin, V., Lukyanova, T., \& Igumentseva, A. (2017). Analysis of the manufacturing process of the case-shaped casting in the sand mould. ISJ Theoretical \& Applied Science, 06 (50), 14-52.

8. Chemezov, D. (2017). Shrinkage of some metal alloys after solidification. ISJ Theoretical \& Applied Science, 06 (50), 87-89.

9. Chemezov, D. (2017). Stress fields in a steel casting. ISJ Theoretical \& Applied Science, 05 (49), 165-172.

10. Chemezov, D., Bayakina, A., Bogomolova, E., \& Lukyanova, T. (2017). To the question of the solidification process of steel castings with different wall thicknesses. ISJ Theoretical \& Applied Science, 03 (47), 38-41. 